\title{
The Influence of Frictional Facing Thickness on the Contact Pressure Distribution of Multi-Disc Dry Clutches
}

Hamburg University of Technology System Technologies and Engineering Design Methodology Germany

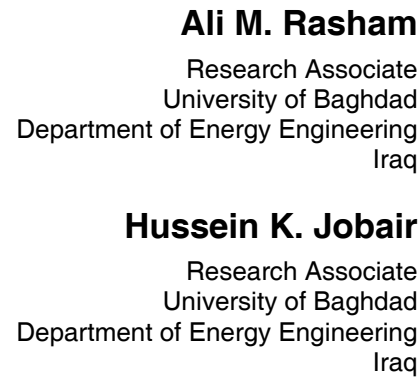

Ali M. Rasham

Research Associate ring aq
Frictional heat is generated when the clutch starts to engag. As a result of this operation the surface temperature is increased rapidly due to the difference in speed between the driving and driven parts. The influence of the thickness of frictional facing on the distribution of the contact pressure of the multi-disc clutches has been investigated using a numerical approach (the finite element method). The analysis of contact problem has been carried out for a multiple disc dry clutch (piston, clutch discs, separators and pressure plate). The results present the distribution of the contact pressure on all tShe surfaces of friction discs that existed in the friction clutch system. Axisymmetric finite element models have been developed to accomplish the contact analysis in this work. Thickness of the frictional facing of a clutch disc is a significant parameter that affects the elastic and thermal behaviors of a dry friction clutch. The results proved that the magnitudes of the contact pressure are increased dramatically when the thickness of the friction facing decreases.

Keyword: Contact analysis, dry friction clutches, finite element analysis.

\section{INTRODUCTION}

Friction clutch is an essential machine element which is used widely in the automotive applications. The friction force is produced when two or more bodies are pressed together and there is relative motion between them. This friction force is responsible to transmit the torque from the driving element to the driven element (e.g. friction clutch). There are different kinds of friction clutches; one of them is designed to be the friction surfaces which are flat and at a $90^{\circ}$ with the rotation axis. Multi-disc friction clutches are used to transmit a high torque capacity, but for this kind of clutch the amount of heat transfer is limited, and it is too difficult to cool it. So, it is appropriate for high-load and low-speed applications. For high-speed dynamic loads, it is better to use a few friction surfaces [1]. Figure 1 shows the main components of a typical dry friction clutch system (multiple friction discs). The mechanical designers work in various fields continuing to overcome the challenges to find the solution for the contact problem.

It can be seen that the contact issue in different kinds of machines used in different engineering applications. The forces will be transferred between portions based on contact which happens between them. The contact problem has covered a wide range (length and time) in various mechanical applications, from nano-scale to the macroscopic level and from hyper-velocity impact to quasi-static contact. Generally, machines consist of many parts and joints such as pins and bolts that are

Received: May 2017, Accepted: September 2017

Correspondence to: Assist. Prof. Dr. Oday I. Abdullah

Hamburg University of Technology,

Denickestrasse 17, 21073 Hamburg, Germany

E-mail: oday.abdullah@tuhh.de

doi:10.5937/fmet1801033A

(C) Faculty of Mechanical Engineering, Belgrade. All rights reserved utilized to join them together. Therefore, a deep investigation for the effective variables and parameters on the pressure contact distribution is necessary. In order to improve the quality and lifetime of different mechanical parts or systems (e.g. friction clutches and brakes, gears, seals, etc.), the computation of the contact forces accurately is considered essential issue. The mechanical designing process is mainly dependent on the understanding of the contact phenomenon to enhance the lifecycle and decrease the wear rate of contact bodies.

Al-Shabibi and Barber [2] investigated the thermomechanical performance of the sliding systems using an approximation approach (Reduced Order Model) which describes the dominant perturbation or eigenfunctions in one value or more. Their numerical model represented the sliding system with a modest number of nodes to find the temperature field, and the distribution of contact pressure. They proved that the results obtained from their model are accurate for friction brakes or clutches during the first period of engagement, when the sliding speed is greater than the critical sliding speed. In the last period of the engagement when the value of sliding speed is close to the critical value and the eigen-values is developed into clusters. Subsequently, the fine discretization is required to obtain accurate solutions.

Later, Al-Shabibi and Barber [3] studied the transient non-homogeneous thermoelastic issue including the frictional heating. They divided the problem into two parts: the homogenous and the particular systems. The solutions based on the superposition approach for the homogenous and the particular systems are used to find the number of nodes necessary to satisfy all conditions of their case study (initial and boundary conditions). They proved that their numerical model is va- 


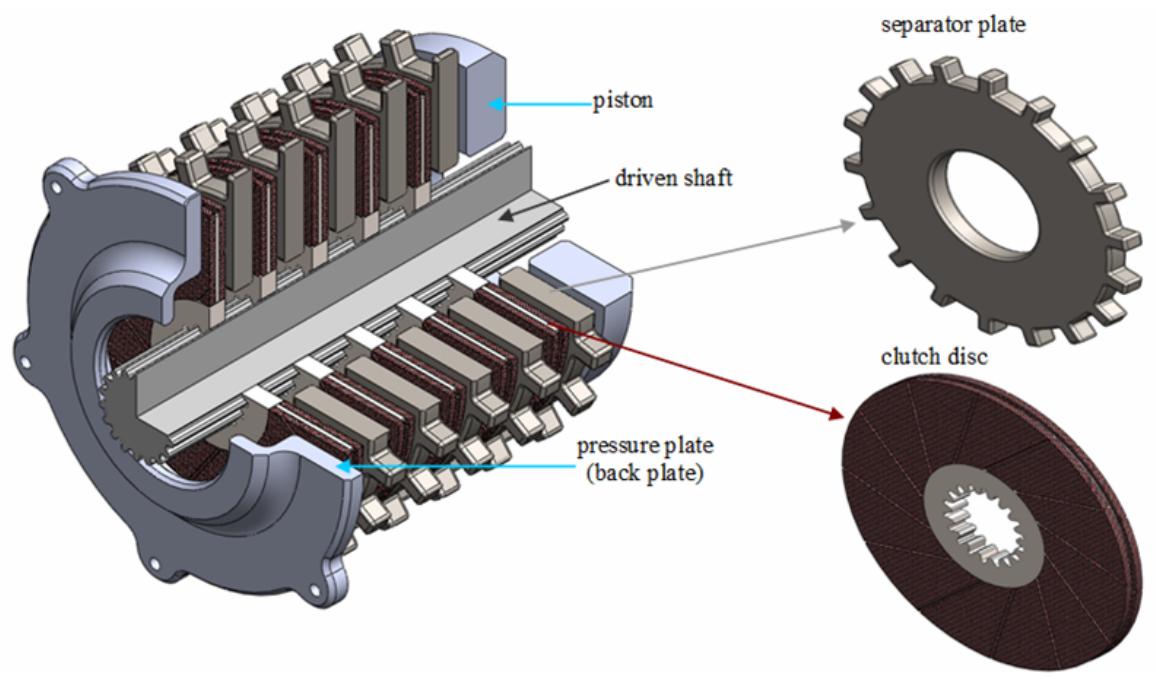

\section{Figure.1. Main parts of a multi-disc clutch system}

lid for low to average values of the standard working sliding speed of friction clutch. In case when the value of sliding speed is high, the values of contact pressure are negative. These results proved the existence of separation between the contact parts. Furthermore, they investigated the influence of the sliding speed on the behavior of the thermoelastic of clutch. The results of their approach were confirmed compared with the direct finite element simulation.

Shahzamanian et al. [4] investigated the problem of thermoelastic contact phenomenon of the friction brake (functionally graded) which is subjected to the thermal load due to the friction phenomenon between the contact parts using a numerical approach (the finite element method). They supposed that the properties of disk material can be represented with power function that varies in the radial path. The internal surface is considered a metal while the external surface is considered ceramic. The material of the pad element is assumed homogeneous. They calculated the thermal load based on the coulomb friction low. Their results proved that the location of the highest magnitude of the displacement in the radial direction of the brake disk isn't at the external surface. They concluded that the contact status for all regions that located between the pad and the brake disk is full when the value of the thickness ratio (pad thickness /brake disk thickness) is 0.66 .

Abdullah et al. (2013a, 2013b, 2013c, 2014a. 2014b, $2014 \mathrm{c}, 2015 \mathrm{a}$ and 2015b) investigated the temperature distribution as well as the energy dissipated of a friction clutch working under dry condition during the starting of engagement based on uniform pressure and uniform wear assumptions. They also investigated the influence of contact pressure between surfaces on the distribution of temperature and the energy balance of the friction clutch disc by applying two approaches. These approaches are: the heat partition ratio which is used to calculate the heat flux for each single part particularly whereas the second approach uses the entire amount of heat generated for the whole model utilizing the contact model. Furthermore, they investigated different parameters and factors that affect the behaviour and performance of a friction clutch system such as enga- gement time, function of sliding velocity, heat generated and disc radius ratio (inner radius/outer radius) during the beginning of engagement.

In this paper, new finite element models are presented to investigate the contact problem of the dry friction clutches that consist of multiple friction discs (the main parts: back plate, clutch discs, separators and piston) when all elements of a friction clutch are pressed together and clutch begins to work. This paper analyzes the influence of friction material thickness of clutch disc on the values and distribution of the contact pressure for each surface of friction discs of a dry friction clutch system.

\section{FINITE ELEMENT ANALYSIS}

This section presents the procedure to build a mathematical contact model of the dry friction clutch system (multiple friction discs) using ANSYS software. The first significant step in this procedure is the modeling; because of the symmetry in the geometry (frictional facing without grooves) and the boundary conditions of clutch system (taking into account of the influence of the applied pressure). An axisymmetric model based on the finite element method was developed to represent the elastic issue that occurs in a friction clutch system. Figure 2 exhibits the complete elastic model of clutch system (multiple friction discs) with constraints and load conditions.

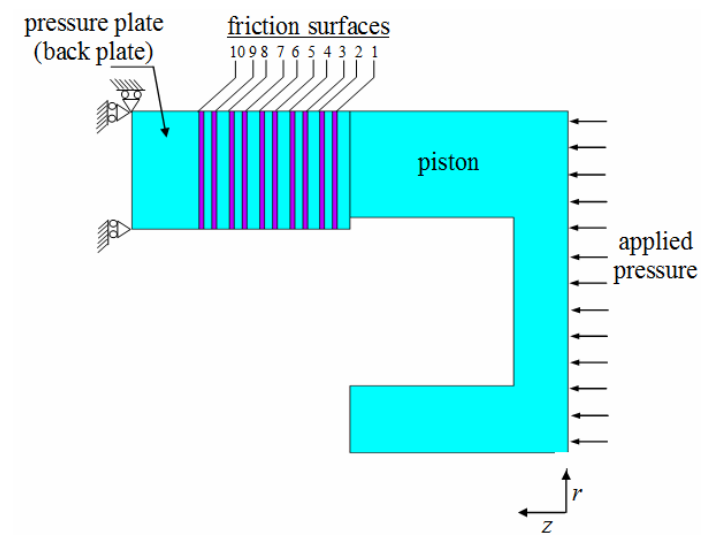

Figure 2. Contact model with boundary conditions of a multi-disc clutch system 
There are three basic types of contact assumed in different applications of mechanical field. These types of contact are: single contact, node-to-surface contact, and surface-to-surface contact. The most frequent type of contact assumed in contact analysis is surface-tosurface; it can be employed for bodies which may have arbitrary figures with considerable contact surfaces. This kind of contact is quite efficient for bodies that have high magnitudes of relative motion, for example a block slipping over a plane or sphere slipping inside a groove [Contact Technology Guide (2010)]. The type of contact which is assumed in this analysis is surface-tosurface. Five algorithms being used for the proposed type of contact in this paper (surface-to-surface contact), (a) Penalty method: based on this algorithm the correlation between two surfaces in contact can be found using a constant factor (spring), as illustrated in Figure 3. The force of contact (pressure) that occurs between two contacting bodies is [Contact Technology Guide (2010)]:

$$
F_{n}=k_{n} x_{p}
$$

where $F_{n}$ is the contact force, $k_{n}$ is the contact stiffness, and $x_{p}$ is the space between two existing nodes or separate contact bodies (penetration or gap).

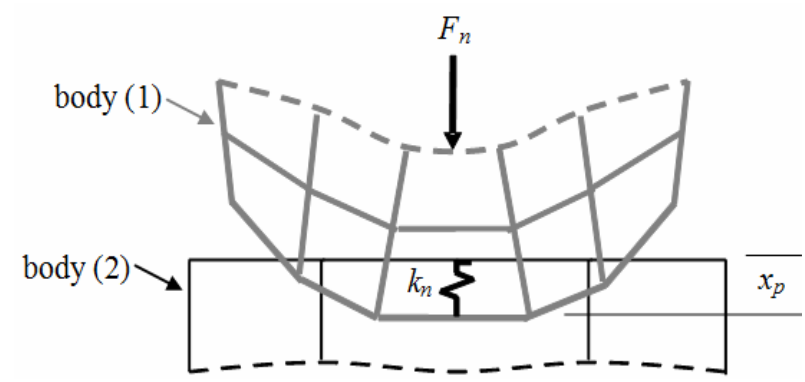

Figure 3. Contact stiffness between two contacting bodies

(b) Augmented Lagrange (default): The principle of this kind of algorithm is based on the method of iterative penalty. The final value of penetration is less than the permitted value of tolerance and the constant traction (stresses due to friction and contact pressure) is augmented during the iterations to reach the equilibrium status. In general this method is less affected by the value of constant stiffness and it leads to improving the conditioning. The contact force form (contact pressure) that occurs between two contacting bodies is,

$$
F_{n}=k_{n} x_{p}+\lambda_{L}
$$

where $\lambda_{L}$ is the component of Lagrange multiplier.

(c) Lagrange multiplier on contact normal and penalty on a tangent: This type of algorithm applies Lagrange multiplier method in the normal contact condition and the penalty method (tangential contact stiffness) in the frictional plane condition. This algorithm permits for the sliding that occurs in the sticking contact condition, while it does not allow the occurrence of any penetration (zero penetration). The parameters needed to obtain the accurate results are the maximum permissible value of elastic slide and chattering control. (d) Pure Lagrange multiplier on contact normal and tangent: This type of algorithm obliges the penetration to be zero in condition of full contact and slipping to be zero in the case of sticking contact. The advantage of using this algorithm is neglect the effect of contact stiffness in calculations, but it needs parameters of chattering control. The disadvantage of using this algorithm is that it requires further iterations to reach the stability condition of contact. Therefore, the computa-tion time needed to solve a contact problem using this method is higher than computation time needed when using augmented Lagrangian method to solve the same problem.

(e) Internal multipoint constraint: This algorithm assumes no separation contact to build the contact model. It is used to simulate different types of bonded contact models (e.g. kinematics constraints and contact assemblies).

The magnitude of penetration is specified based on the correlation between the contact and target surfaces for contact case study. Lower values of penetration will appear in the contact problem when the contact stiffness values are high; in this case the solution will face difficulties in the convergence phase and illconditioning of the stiffness matrix. On the other hand, a certain value of penetration will appear in the contact problem when the contact stiffness values are low; in this case the difficulties in the convergence phase will reduce to obtain the results. The contact stiffness of an element of area $A_{e}$ is computed applying the following formula [Mohr (1980)]

$$
F K N_{i}=\int\left\{N_{i}\right\}(e)\left\{N_{i}\right\}^{T} d A_{e}
$$

where $N_{i}$ and $e$ are the shape function and the stiffness of the elastic restraining (function of material properties). In Ansys software, in the case of bulk deformation, the suitable value of the contact stiffness factor $(\mathrm{FKN})$ is equal to 1 . A small magnitude of a contact stiffness factor $(F K N=0.1)$ is recommended in the case when bending deformation is the major part of the solution [Contact Technology Guide (2010)]. In this analysis, the algorithm which is used to compute the distribution of the contact pressure on the surfaces of friction discs is Augmented Lagrange.

In all accomplished computations in this paper, materials properties are supposed to be isotropic and homogeneous. Table 1 records the materials properties, dimensions and operational parameters. The axisymmetric model based on the finite element method of a friction clutch system (multiple friction discs) is shown in Figure 4.

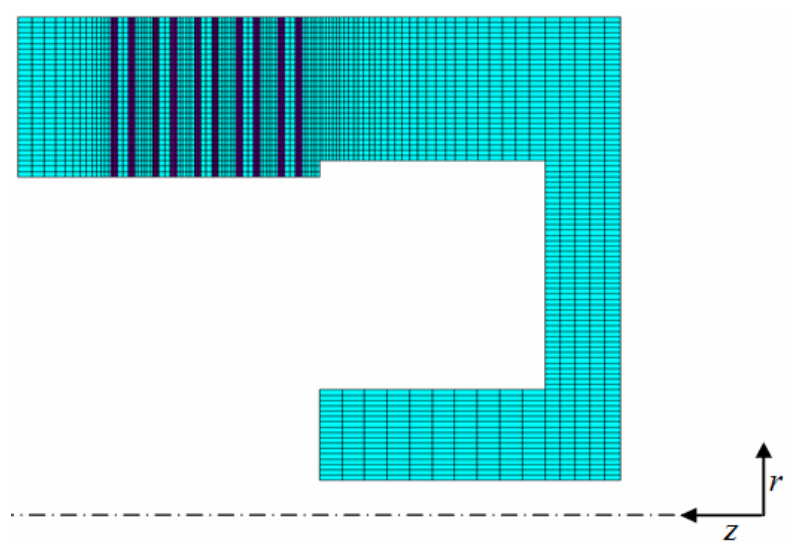

Figure 4. Axisymmetric finite element model of a multi-disc clutch (no. of elements $=3790)$ 
Table 1. Materials' properties and operations' parameters

\begin{tabular}{|l|c|}
\hline \multicolumn{1}{|c|}{ Parameters } & Values \\
\hline Inner disc radius of friction clutch disc, $r_{i}[\mathrm{~m}]$ & 0.052 \\
\hline Outer disc radius of friction clutch disc, $r_{o}[\mathrm{~m}]$ & 0.067 \\
\hline $\begin{array}{l}\text { Thickness of clutch disc including the friction } \\
\text { facing, } t_{t}[\mathrm{~m}]\end{array}$ & $\begin{array}{c}0.0019 \\
3\end{array}$ \\
\hline Thickness of friction facing, $t_{c}[\mathrm{~m}]$ & $\begin{array}{c}0.0005 \\
3\end{array}$ \\
\hline Inner disc radius of pressure plate, $r_{i p}[\mathrm{~m}]$ & 0.052 \\
\hline Outer disc radius of pressure plate, $r_{o p}[\mathrm{~m}]$ & 0.067 \\
\hline Thickness of pressure plate, $t_{p}[\mathrm{~m}]$ & 0.0074 \\
\hline Inner radii of piston, $r_{i f l}$ and $r_{i f 2}[\mathrm{~m}]$ & 0.0235 \\
\hline Outer radii of piston, $r_{o f l}$ and $r_{o f 2}[\mathrm{~m}]$ & 0.0535 \\
\hline Thicknesses of piston, $t_{f l}$ and $t_{f 2}[\mathrm{~m}]$ & 0.032 \\
& 0.067 \\
\hline Applied pressure, $p_{a}[\mathrm{MPa}]$ & 0.006 \\
\hline $\begin{array}{l}\text { Coefficient of friction, } \mu[1] \\
\text { piston and clutch plate. } E_{p}, E_{s}, E_{f}, \text { and } E_{c p}[\mathrm{GPa}]\end{array}$ & 200 \\
\hline $\begin{array}{l}\text { Poisson's ratio of friction material, pressure plate, } \\
v_{c}, v_{p}, v_{s}, v_{f}, \text { and } v_{c p}\end{array}$ & 0.25 \\
\hline Number of friction clutch disc, $n_{p}[1]$ & 0.2 \\
\hline Young's modulus of friction material, $E_{c}[\mathrm{GPa}]$ & 0.3 \\
\hline and clutch plate. & 1 \\
\hline
\end{tabular}

\section{RESULTS AND DISCUSSIONS}

The effect of the frictional facing thickness on the magnitude and distribution of contact pressure that occurs on the surfaces of friction discs of a friction clutch system has been investigated. Four different thicknesses ( 0.25 to $1 \mathrm{~mm})$ were chosen in this analysis. Figures 5-8 display the variation of the normalized contact pressure with disc radius at selected frictional surfaces $(f . s=1,5$, 7 and 10). Figure 9 shows the maximum values of the contact pressure for selected friction surfaces using different friction facing thicknesses.

The most important point observed from the results is that the reduction in the frictional facing thickness causes increasing in the contact pressure values (i.e. using thin frictional facing causes increase in contact pressure and deformation values, and vice versa). In the case when a friction disc is thick (thick fractional facing), low values of the contact pressure on the contact surfaces are generated. This situation occurs due to the increasing in the structural stiffness. Also, it can be observed that the distribution of contact pressure is smoother when using thick frictional facing. The percentage increase in the normalized contact pressure is found to be $3.1 \%$ of the 10th friction surface when the thickness changes from $0.25 \mathrm{~mm}$ to $1 \mathrm{~mm}$.

The results showed that the highest values of contact pressure are located near the internal radius $\left(r_{i}\right)$ and the lowest contact pressure values are located at external $\operatorname{disc}\left(r_{o}\right)$ for all surfaces of friction discs.

The influence of friction facing thickness is increased in the presence of thermal deformation during the slipping period. Therefore, the thin frictional facing will have more difficulty to follow the thermal distortion induced by the frictional heating and leads to the non-uniformities in the distribution of the contact pressure and surface temperature more quickly.

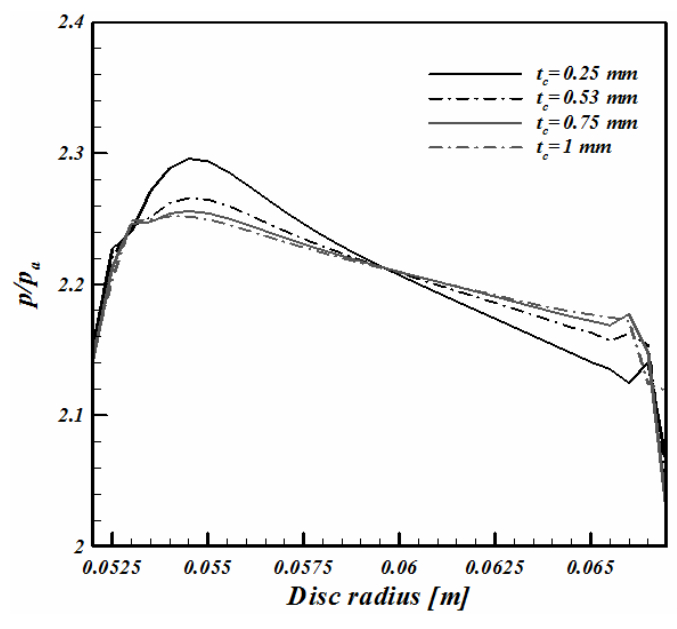

Figure 5. Variation of the normalized contact pressure with disc radius using different friction facing thicknesses $(f . s=1)$

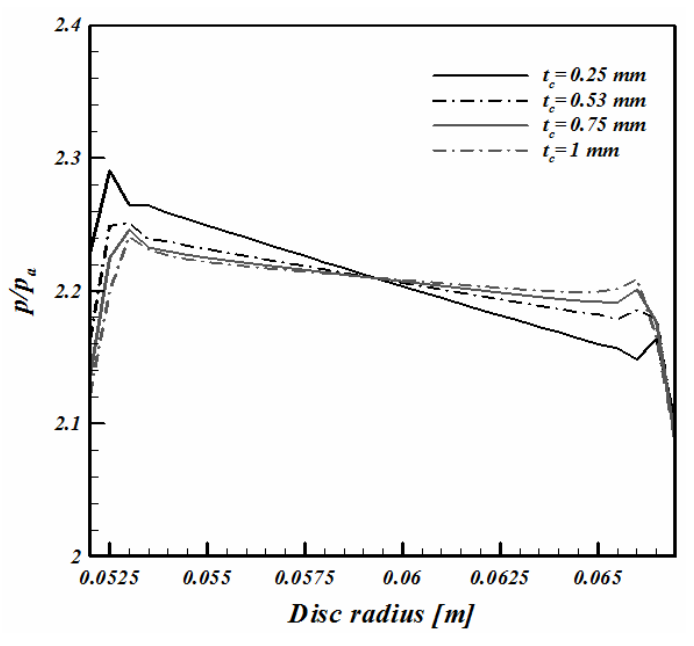

Figure 6. Variation of the normalized contact pressure with disc radius using different friction facing thicknesses $(f . s=5)$

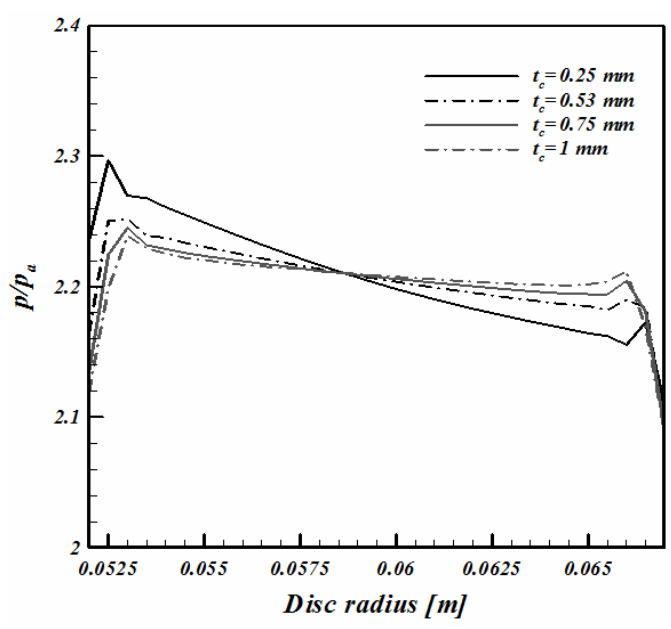

Figure 7. Variation of the normalized contact pressure with disc radius using different friction facing thicknesses $(f . s=7)$ 


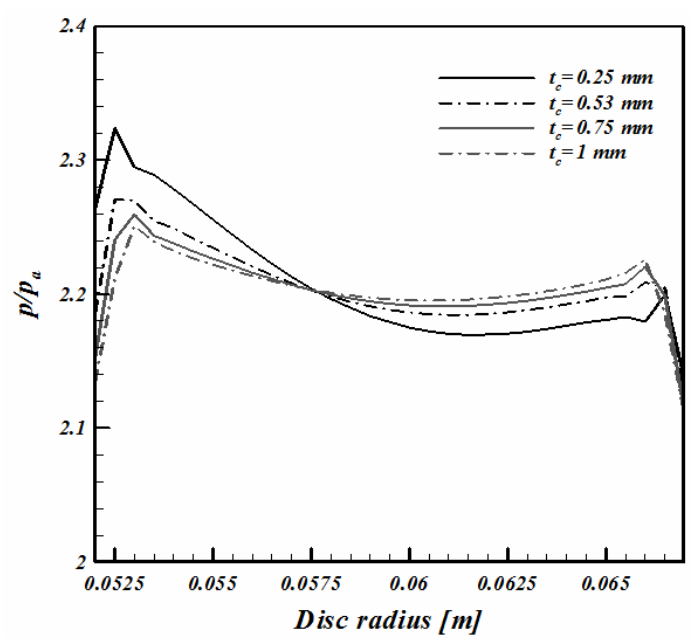

Figure 8. Variation of the normalized contact pressure with disc radius using different friction facing thicknesses $(f . s=$ 10)

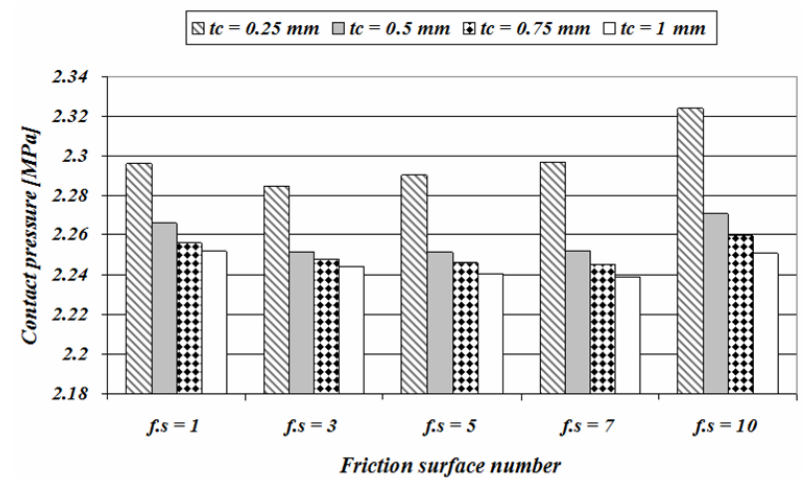

Figure 9. Maximum values of the contact pressure for selected friction surfaces using different friction facing thicknesses

\section{CONCLUSIONS AND REMARKS}

In this paper, a numerical method (finite element method) is used to investigate the problem of contact that appears between the contacting discs of a multi-disc friction clutch. Axisymmetric models are developed to represent the elastic problem of a friction clutch system.

Thickness of the friction materials of a clutch disc is considered an essential parameter which affects the magnitude and the distribution of the contact pressure on the contacting surfaces. This effect is more significant when the friction clutch starts to engage (slipping period) due to the frictional heat generated between the contacting surfaces.

There are other important factors that may lead to the failure of the friction clutch such as cracks that exists in contact surfaces and lasting deformations. These dissadvantages cause change in the distribution of contact pressure and subsequently the actual contact area change too.

The contact pressure focuses on a small zone of the nominal contact area as a result of the thermal deformations. Also, the defected or improperly machined back plate (such as large deformation, thermal cracks, etc.) causes many problems. One of these problems is concentration of contact pressure on small regions of the nominal frictional interface (e.g. bands and/or spots). Owing to this problem, it is essential when fitting a new friction clutch (in the case when the clutch surfaces are damaged or surface worn) to a vehicle to guarantee that the back plate is in proper condition, in order to avoid any possible premature damage to occur in the system of friction clutch.

\section{ACKNOWLEDGEMENTS}

The second affiliation of the first author, Asst. Prof. Dr. Oday Ibraheem Abdullah, is University of Baghdad Department of Energy Engineering, Iraq.

\section{REFERENCES}

[1] Bharat, B.: Principles and Applications of Tribology, A Wiley-Interscience Publication, Boston, 2010.

[2] Al-Shabibi, A. and Barber, J. R.: Transient solution of a thermoelastic instability problem using a reduced order model, International Journal of Mechanical Sciences, Vol.44, No.3, pp.451-464, 2002.

[3] Al-Shabibi Abdullah and Barber J. R.: Transient solution of the unperturbed thermoelastic contact problem, Journal of Thermal Stresses, Vol. 32, No. 3, pp. 226-243.

[4] Shahzamanian, M. M., Sahari B. B, and Bayat M.: Finite element analysis of thermoelastic contact problem in functionally graded axisymmetric brake disks, Journal of Composite Structures, Vol. 92, No. 7, pp. 1591-1602, 2010.

[5] Abdullah, O. I., Schlattmann, J, and Pireci, E.: Optimization of shape and design parameters of the rigid clutch disc using FEM, FME Transactions, Vol. 41, No. 4, pp. 317-324, 2013.

[6] Abdullah, O. I., Schlattmann J., and Lytkin M.: Effect of Surface Roughness on the Thermoelastic Behaviour of Friction Clutches, FME Transactions, Vol. 43, No. 3, pp. 241-248, 2015.

[7] Abdullah, O. I., Schlattmann, J., Al-Shabibi, A. and Akhtar, M.: Investigation of Thermoelastic Behaviour of the Dry Clutches Under Different Boundary Conditions, Journal of the Balkan Tribological Association, Vol. 20, No. 3, pp. 395408, 2015.

[8] Abdullah, O. I., Akhtar, M. and Schlattmann, J.: Investigation of Thermo-elastic Behavior of Multidisk Clutches, Journal of Tribology, Vol. 137, No. 1, pp: 1-9, 2015.

[9] Abdullah, O. I. and Schlattmann J.,: An Investigation into the Thermal Behavior of the Grooved Dry Friction Clutch, Journal of Tribology, Vol. 136, No. 3, pp. 1-6, 2014.

[10] Abdullah, O. I. and Schlattmann J.,: Computation of Surface Temperatures and Energy Dissipation in Dry Friction Clutches for Varying Torque with Time, International Journal of Automotive Technology, Vol. 15, No. 5:733-740, 2014.

[11] Abdullah, O. I., Schlattmann, J. and Al-Shabibi, A.: Thermo-Mechanical Analysis of the Dry Clutches under Different Boundary Conditions, Tribology in Industry, Vol. 36, No. 2, pp. 172-180, 2014. 
[12] Abdullah, O. I. and Schlattmann J.,: Stresses and Deformations Analysis of a Dry Friction Clutch System, Journal of Tribology in Industry, Vol. 35, No. 2, pp. 155-162, 2013.

[13] ANSYS: Contact Technology Guide, ANSYS, Inc, 13, 2010.

[14] Mohr, G. A.: A Contact Stiffness Matrix for Finite Element Problems Involving External Elastic Restraint, Journal of Computer and Structures, Vol. 12, No. 2, pp.189-91, 1980.

\section{УТИЦАЈ ДЕБЉИНЕ ФРИКЦИОНЕ ОБЛОГЕ НА ДИСТРИБУЦИЈУ КОНТАКТНОГ ПРИТИСКА КОД СУВОГ ВИШЕЛАМЕЛНОГ КВАЧИЛА}

Када се квачило укључује трењем генерише се топлота и на површини температура нагло расте као последица разлике у брзини између погонских и погоњених делова. Утицај дебљине фрикционе облоге на дистрибуцију контактног притиска код сувог вишеламелног квачила је истражен нумеричким (ФЕМ) приступом. Анализира се проблем контакта код делова сувог вишеламелног квачила (клипа, ламела, сепаратора и потисне плоче). Резултати показују дистрибуцију контактног притиска на свим површинама фрикционих ламела код система сувог квачила. У циљу анализе контакта развијени су модели асиметричних коначних елемената. Дебљина фрикционе облоге код ламеле квачила је значајан параметар који има утицаја на еластично и термичко понашање сувог вишеламелног квачила. Висина контактног притиска нагло расте са опадањем дебљине фрикционе облоге. 